\title{
Chinese People's Understanding of the Korean Unification Issue
}

\author{
Debin Zhan \\ Assistant Professor, Shanghai Institute of Foreign Trade, China \\ E-mail: zhandebin@hotmail.com
}

Hun Kyung Lee (Corresponding author)

Associate Professor, Graduate School of Northeast Asian Studies, Dong-A University, Korea

E-mail: lawseoul@hotmail.com

Received: May 27, 2011

doi:10.5539/ass.v8n3p63
Accepted: August 9, $2011 \quad$ Published: March 1, 2012

URL: http://dx.doi.org/10.5539/ass.v8n3p63

\begin{abstract}
A divided Korean peninsula has troubled Chinese diplomacy and has negative effects on Chinese national interest. The main factors such as the well-established historical relations between China and the Korean peninsula, the close geopolitics relations, and the Korean peninsula with the Sino-U.S. interaction influences the Chinese people's view of the Korean unification issue.

From national interest perspective, China hopes to see Korean unification that would be in favor of China, at least it will not bring negative influence. China also desires for a unified Korea that is neutral or friendly towards China, and for the withdrawal of the U.S. armed forces from the Korean peninsula. Otherwise, China wants to maintain the status quo and present situation. Although this is not supported by the Koreans, China will fully support reconciliation and cooperation, political dialogue, economic and cultural exchanges between North and South Korea. It is believed to contribute to keeping good relations between them, leading to a peaceful process of unification in the end.
\end{abstract}

Keywords: Chinese people, Korean peninsula, Korean unification

\section{Introduction}

From this preliminary investigation, it is difficult to find Chinese views on the Korean unification issue from scholars, netizens, books, articles, etc. In most of the cases found by this study, scholars talk about the relationship between China and two Koreas, generally mentioning several aspects, such as the historical origin, geopolitics relations, Sino-U.S. relations, and so on. Of crucial importance for this paper is to uncover the Chinese people's view on the Korean unification issue, not the Chinese government's view.

In the past, the Korean people, suffering from the pain of division of the Korean peninsula, have been eager to pursue reunification. As the 61th anniversary of the Korean War is commemorated, the issues of peace, stability, and reunification of the Korean peninsula once again have become a hot topic. In discussing the Korean unification issue, China has been an unavoidable external factor at all times. In fact, the Chinese government has been concerned about the issue and has declared its respect of the Korean people's desire for peaceful Korean reunification. By the same token, it has supported implementation of the peaceful process of unification by Koreans themselves. This position was made clear right after China and South Korea normalized relations in 1992.

The Chinese position was made clear during the June 2000 China-South Korea summit in the Chinese Foreign Ministry's declaration (Lianhe Zaobao, June 14, 2000): "China, as a neighbor of the Korean peninsula, on the premise of no intervention from outside, constantly supports the two parts of Korea to improve their relations and cultivate trust by means of dialogue and contact until they finally achieve autonomous and peaceful unification." This view has often been reiterated when Chinese leaders meet with North and South Korean leaders. 
Nevertheless, Chinese support for Korean unification seems to be doubted by many South Korean scholars and much of the public. Some American scholars predict that if North Korea suddenly collapses, China would act to control the process, dispatching troops crossing the Yalu River and Tumen River to build a security buffer zone to insulate it from the chaos and refugees. Many are of the opinion that the Chinese do not desire Korean unification, and rather want to keep a permanent division and maintain the status quo on the Korean peninsula. This viewpoint was widely accepted by South Korean scholars, the media, and the public. Is this an accurate view of the Chinese intentions? In order to answer this question, the paper intends to analyze the Chinese people's view on the Korean unification issue.

\section{Chinese people's view on Korean issues}

Before analyzing Chinese intentions on the Korean unification issue, it is necessary to understand the Chinese people's point of view. In general, there are three main factors that influence the Chinese people's view of the issue: (1) the well-established historical relationship between Chinese and Korean peninsula; (2) the close geopolitical links of the region; and (3) the Sino-U.S. interaction on the Korean peninsula. These factors are fully described in this chapter.

\subsection{Korean peninsula in historical perspective}

Both China and Korea are neighbors in the northeastern part of Asia. Historically, Korea had been heavily influenced by China for about 2,000 years in the past, due to sharing a border. As a result, on the one hand, Korean dynasties benefited considerably from Chinese dynasties; on the other hand, Korean dynasties suffered extremely from Chinese dynasties (Son 2003, 1).

Close ties between China and Korea go back to the eighth century B.C. Under the Chinese Western Han and Eastern Han Dynasty (202 B.C. to A.D. 220), frequent trades were conducted between China and Korea. Thousands of years have past, but the Chinese and Korean relationship has not been interrupted. Though, it is said (Wang 2006, 32) that "sometimes it was tight and sometimes loose."

The Sino-Korean relationship in ancient times was determined by the suzerain system (Hua Yi order). In a suzerain system, a dominant state controls the foreign relations of tributary states but allows them limited autonomy in their internal affairs. The tributary states, while subservient to the dominant state, can benefit militarily, economically, and culturally from the relationship. The suzerain state system also achieves stability along the dominant state's borders.

Among ancient suzerain states, the relationship between China and Korea was a typical suzerain one. In the Ming Dynasty (1368-1643) and Qing Dynasty (1644-1911), the Sino-Korean suzerain system became a fixed model. Korean dynasties of the Chosun era (1392-1910), like other neighbor countries, had to choose between paying tribute to the China emperor or not. Successive Korean dynasties chose to pay tribute, and throughout the pre-modern era the peninsula's proximity to the center of Chinese civilization assured a high degree of Chinese political, economic, and cultural influence (International Crisis Group 2006, 1). They also dispatched diplomats to China every year on a determined time, celebrating the Lunar New Year Festival, the anniversary of the assumption of the emperor to the throne, the birth of prince, and the like. In return, China, as the central state, offered advanced technology, books and records, and knowledge about the political system. Confucianism played a key role on making the relations between them such a suzerain-subject relationship as "Confucian doctrines of hierarchy in the Chosun dynasty... informed a foreign policy known as 'serving the great'(sadae), that great thing being China - and not just China, but China of the Ming (Cumings 1997, 51)."

Nonetheless, in retrospect, exchange of knowledge and technology in the area of politics, economy, and culture, religions (Confucianism and Buddhism), and even military was not tantamount to China wanting to take control of the Korean peninsula. For centuries, Chosun retained a favorable tribute relationship with China, and the latter listed the former as an peaceful and trustworthy state. China carried out a role as a patron for the development of Korea's political and cultural civilization under feudal regime until 1910. That is why today most Koreans feel more familiar and comfortable with the Chinese than any other foreign people (Son 2003, 5).

\subsection{Korean peninsula from the geopolitical perspective}

China has always considered the geopolitical factor regarding its relationship with the Korean peninsula. From 221 B.C. to the twentieth century, Korea has experienced about 720 foreign skirmishes, 53 foreign aggressions, and 5 wars between foreign nations that took place in Korea (Kang 1997, 53-63). The Korean peninsula was of primary importance for China after the Ming Dynasty moved the Chinese capital from Nanjing to Beijing. Since then, the political and military significance of the Korean peninsula has been emphasized. In 1592, Japan invaded Korea. Korea requested reinforcements from the Ming Dynasty's government. After a heated debate, the 
Ming Dynasty government decided to dispatch troops to resist the Japanese invader Toyotomi Hideyoshi. After that, China formed the concept of the "interdependence of two neighboring states (If the lips are gone, the teeth will be cold)," which meant that defending the Korean peninsula was the same as defending China. Under the divided situation of Korean peninsula, the logic of "teeth and lips" would be applied for North Korea, but not South Korea.

Because of the geopolitical factor, the Korean peninsula is a core place where surrounding powers have confronted each other. From a historical point of view, great powers possess conflicting interests in this area, from the Sino-Japanese War to the Russo-Japanese War, from the Pacific War to the Korean War, China, Japan, Russia, and the United States have contested furiously in this area (Cai 2007, 127-128). This situation would be called "stunted realism (Rozman 2004)." Despite globalization, the continued or even heightened salience of past history, mutual power suspicions, and barely contained power competition remain broadly evident (Pollack 2009, 2 ), and multiply dark future outlooks for geostrategic multilateral cooperation in the region.

On the Korean peninsula, history and geography have combined to make North Korea a cordon sanitaire for China against the U.S. military presence in Korea and, in the larger historical sense, against Japanese expansionism (Kim 2004, 166). On the other side, the two Korea's confrontation has become part of the great powers' tug of war. Therefore, the unification of the Korean peninsula concerns not only the internal question of Korea, but also the international question of the great powers since their national interests conflict on the issue of Korea unification (Kang 2009, 55).

Accordingly, unanticipated incidents dramatic changes taking place on the Korean peninsula make the great powers feel nervous. The special geographical location of Korea has ensured its prominent strategic position, and the surrounding countries have promoted this strategic importance (Qiangguo bbs 2009). From the Korean viewpoint, the Korean peninsula has historically served as the strategic crossroads between the Asian mainland and the Pacific, often becoming either a target for occupation by foreign powers or an area of rivalry among the great powers (Cho 2008, 145).

The U.S. political and military elites understand the geopolitical significance of Korea. The Korean peninsula holds the marine transportation center of Northeast Asia - the Tsushima Strait. Within the strait is the East Sea, which is as important strategic area for the U.S., Russian, and Japanese navies (Liu 2007, 50-51). Considering this, notably, in February 1986, the U.S. Navy Admiralty listed the Tsushima Strait as one of the 16 seaway choke points that needed to be controlled (Chen 2002, 18). Moreover, Zbigniew Brzezinski (1998, 63-64), the former U.S. national security adviser, pointed out in his book The Grand Chessboard that with the end of the Cold War, South Korea has become one of the five vital fulcrum countries; its status even surpasses Japan.

From the above geopolitical logic, the Korean peninsula is still an important and unstable link in Chinese border security. China was afraid that, with its traditional spheres of influence to be antagonized, the U.S. military threats would be expanded not just in Northeast Asia, but also to the East China Sea and Southeast Asia (Park 2008, 270-271). Should the Korean peninsula come under the control of one of the great powers, Northeast China, North China, and East China would be directly threatened and Chinese strategic maneuvering space would be squeezed. If the focus of Chinese security concern shifts to the Northeast area, China could be distracted from the Taiwan issue, southeast marine territory rights, or other strategic considerations. Hence, China might become passive in its foreign policy.

\subsection{Korean peninsula under Sino-U.S. interaction}

The complex situation on the Korean peninsula under the new international environment includes the global financial crisis, the rapid increase of China's influence, the declining relative U.S. power. Therefore, the United States and China have to consider cooperating to solve various regional and global issues, in particular, solving the Korean question, Korean stability and security, and even Korean unification.

After the Cold War, the United States was the only world superpower. This was its "unipolar moment." The United States was not only dominant but could in fact further shape the international system, its structure, and regimes (Maass 2010, 44). Then, the question became: How does this kind of supreme status allow the United States to allocate its foreign strategy in maintaining its hegemony and to establish a world order lead by America. To achieve this, the basic U.S. strategies are to ensure it can continue to enjoy the status of the world's sole superpower, to prevent the emergence of regional hegemony, to maintain regional security and stability in Northeast Asia, and to control Eurasian geopolitics (Zhan 2008, 37). But it has not succeeded to lead multilateral security cooperation in Northeast Asia, in particular, on the account of holding each other in check, as not taking a dominant position in a security situation rather than facilitating security dialogue and cooperation. 
In order to strengthen its dominant position and prevent a latent challenge in Asia, the United States has drawn support from alliances and multilateral security cooperation mechanism to contain China. At present, in Northeast Asia, the United States garrisons 47,000 and 28,500 soldiers in Japan and South Korea, respectively. South Korea can provide the USA with alliance security assurance and support the US non-proliferation commitments (Cheon 2011, 61). Thus, the United States wants to strengthen its bilateral alliances, and at the same time strengthen the U.S., Japan, and South Korea triangle alliance. This means that the United States wants to maintain military pressure on North Korea, maintain a balance of power in Northeast Asia, and achieve the goal of maintaining its strategic power in Asia and the Pacific region (Xu 2003, 59).

Furthermore, the United States is helping Japan build its missile defense system using the excuse that North Korea is developing missiles and nuclear weapons. The United States has persuaded the Seoul government to construct a U.S., Japanese, and South Korean missile defense system, and has criticized South Korea for not joining the Proliferation Security Initiative (PSI), which is headed by the United States. But the South Korean administrations of Kim Dae Jung and Roh Moo-Hyun have seemed reluctant to accept the missile defense system. After South Korean conservatives came to power, the United States resurrected its dream of regional missile defense and persuaded South Korea to join PSI as a result of North Korea's launching its Unha-2 rocket (Hwang 2009). At the same time, with the strengthening of U.S.-South Korean alliance and Japan becoming a militarily powerful state, the importance of Korean peninsula is increasing rather than decreasing. From Chinese eyes, the stationing of U.S. armed forces on the Korean peninsula based on U.S.-South Korean alliance is biggest obstacle to Korean unification.

\section{Effects on Korean division}

Some of the Chinese people are not willing to see the Korean unification that is mainly driven by national interest. But, every thing has the dual character, i.e., a divided Korean peninsula causes troubles for Chinese diplomacy and has a number of negative effects on Chinese national interest.

First, the continued division of Korea could induce another war. Since the division between the North and the South in the Korean peninsula, the two Korea's have maintained a relationship in which tensions rise and fall. North Korea, with an army of more than 1.2 million, sometimes provokes conflict with or without intention, while the United States and South Korea's 0.6 million troops might be tempted to lure the North Koreans to launch an attack. The United States and South Korea carry out several large-scale military exercise every year, exercises aimed at North Korea and related nations. North Korea has often mobilized its armed forces in response. This brings about heightened tensions on the Korean peninsula.

Because the two Koreas are still in a state of war, North and South Korea have tense relations; therefore, the Korean peninsula could possibly create an armed conflict at any time. Should conflict were to occur on the Korean peninsula, tensions around the Chinese border would be very high. This could affect the inland part of China and lead to social chaos. For example, Taiwan and Tibet secession groups could seize the chance for independence, and Xinjiang radicals could carry on terrorist attacks and so on.

Second, the divided peninsula could also breed Northeast Asia instability. A stable periphery is one of the primary missions of China's new diplomacy. North Koreans began to flee in the 1990s due to years of economic trouble; the numbers of people fleeing has increased recently. Statistics indicate (The Independent, April 24, 2009) that up to April 2009, the number of North Korean defectors fleeing to South Korea has approached 16,000 .

China is a core stop for North Korean defectors fleeing to United States or South Korea. Massive refugee flows have created serious social and public security issues for Jilin, Liaoning, and other provinces. Moreover, North Korean defectors go through many places in China, search the chance to rush into the diplomacy or folk organizations and lead to chaos in the Chinese social order. Since 2006, no systematic survey was conducted on the number of North Korean refugees in China. Nevertheless, the number is estimated to be between 20,000 and 40,000 (Lee et al 2009, 23). Surveys of North Korean refugees/migrants in the border provinces reveal that almost none left for political reasons, and awareness of the abnormal conditions they live under is usually only bred by contact with foreign religious and charitable organizations inside China (International Crisis Group 2006, 18). The Chinese government as a main responsible nation considers them and thinks that they should not be suffering from persecution or from hunger. But some groups are illegal immigrant, and evenly faked spies. From the view of the Sino-North Korea relationship, China should repatriate them. But whenever Beijing repatriates these illegal immigrants, international society, including the United States and South Korea, tends to condemn Beijing's attitude. Thus, the North Korean defectors issue is always a troublesome one for the Beijing government and a load for China to carry. 
More importantly, if a crisis in the North coming from Kim Jong Il's illness or internal conflict arises, it may cause political instability and create a situation out of control. What is worse, a great number of North Korean residents may flee to the surrounding countries, including China, which is obviously not in line with the smooth execution of Beijing's strategic Northeast development plan.

Third, North Korea is not an obedient ally of China. Starting from the 1950s, North Korea has sometimes played the Chinese-Soviet card - sometimes close to the Soviet Union and sometimes close to China, which makes China doubt North Korea's reliability (Sina Military Forum 2007). In particular, in the nuclear test in October 2006, Pyongyang informed China 20 minutes before the test, while informing Russia earlier.

Reform is the same. For China, if the North Korean regime succeeds in a soft-landing through adopting the reform and open-door model of China, it would have a more significant meaning to China than simply solving the North Korea nuclear issue (Lee 2010, 169). Therefore, although Beijing emphasizes noninterference in internal affairs, China hopes that North Korea will seeks an effective reform model to get rid of the domestic economy difficulties. So, Beijing has invited the North Korean leaders many times to visit China's economical demonstration cities, such as Shanghai, Guangzhou, and Dairen, to experience the reform advantage.

Stability is also wished to China. North Korean contingency situations sharply increase regional instability and unpredictability, and become also a major hurdle to China's development strategy (Kim 2010, 61). However, North Korea has created a crisis on the peninsula repeatedly. Pyongyang has seldom listened to Chinese advise, and rather carried out missile test on July 5, 2006, and tested a nuclear bomb on October 9, 2006. Moreover, North Korea violated Beijing's wish again and launched a long-range rocket on April 5, 2009. North Korea announced its withdrawal from the Six-Party Talks repeatedly and even threatened to carry on an intercontinental ballistic missile test. What is worse, North Korea conducted a second nuclear test on May 25, 2009. Continually, Pyongyang has hesitated to resume the Six-Party Talks as "a path towards institutionalized security cooperation in Northeast Asia in terms of path dependence theory (Hong 2009, 86)."

North Korea's provocative acts were carried out and made Beijing angry, creating distrust between them. Pyongyang leaders have shows a will not to trust China, which results in ignoring Beijing's advice and warnings to North Korea with respect to some cases. Yet China fears to pressure North Korea too much, which could cause a failure of the North Korean regime with significant negative consequences for China (e.g., massive refugee flows toward the Chinese border or North Korean revenge attacks) (Benneu 2009, 28). Thus, China has generally proven unwilling to leverage, coerce, or even deter North Korean actions, undermining China's desired image as a regional superpower (Benneu 2009, 28).

Even more, Pyongyang has seemed to be trying to get rid of Beijing's influence in North Korea. This was shown by Pyongyang's proposal of "tripartite summit discussions" among North Korea, South Korea, and the United States, but not China in the 2007 North and South Korea summit. It is understandable that Pyongyang wanted to approach the United States and exclude China in the arms talks. If North Korea could become an ally for the United States in its effort to implement its Asian and Pacific strategy, it would be a threat to China.

In the meantime, North Korea has created many crises that give the Japanese an excuse to reactivate its militarism, which would aggravate Chinese's security pressure. When North Korea launched the Taepodong 1 rocket in August 1998, Japan used the opportunity to develop its own spy satellite and joined the Theater Missile Defense System (TMD) research effort led by the United States. Japan blatantly showed off that the missile defense system had already deployed, and some politicians even publicly declared that a nuclear weapon must be built, and a preemptive strike on North Korea be implemented.

Fourth, North Korea is a potential competitor to China. In fact, many Chinese people believe that North Korea's development of nuclear weapons is aimed not only at the United States and Japan, but also China. Many Chinese netizens have this kind of view (Tianya Forum Netizen's Article 2006). If North Korea successfully developed nuclear warheads, China would face a grave threat. Above all, China would not be free from a nuclear domino effect in Northeast Asia. To make matters worse, if North Korea encountered a U.S. military attack due to its nuclear proliferation, the Kim Jong Il regime would probably collapse, and South Korea would try to unify the Korean peninsula suddenly. Then, Northeast Asia would present a new strategic pattern that did not favor China. If a North Korean domestic crises started, Chinese diplomacy would face a difficulty choice (Liu 2007, 83).

\section{Maintain the regional status quo}

Many American, Japanese, and South Korean scholars assert that China and Japan are not willing to see Korean unification. Chinese scholars either strongly rebut the assertion or remain silent. Strictly speaking, policies of the four great powers - China, Russia, United States, and Japan - are to maintain the status quo in the Korean 
peninsula as a way of keeping the balance of power in Northeast Asia and avoiding a war as well as a unified Korea that is pro-U.S. or pro-China.

In this regards, some Chinese believe that if Korean unification would not benefit China, the Korean peninsula's present situation should be maintained. The reasons are summarized as follows:

First, from the geopolitical perspective, a divided peninsula can be attributed to the carrying out of the peripheral foreign policy strategy of China. The fratricidal war between North and South Korea caused the division of the Korean peninsula, and the long-term cold war barrier has deepened the division further. The subsequent long-standing inter-Korean antagonism and feelings of distrust and hatred have caused growing mutual fear. Therefore, each side believes the other to be bent on aggression and conquest, to be capable of great brutality and evil-doing, to be something less than human and therefore hardly deserving respect or consideration, to be insincere and untrustworthy, etc (Gladstone 1959, 132).

Therefore, growing hostility, antagonism, deep-rooted mutual distrust and fear, and insecurity feelings have led North and South Korea to be worried about aggressiveness against its opponent. To North and South Korea, respectively, according to the social psychologists (Stagner 1965, 46), the perception of the enemy, even though it may be erroneous, can help to shape reality and bring on a self-fulfilling prophecy: When suspicions run high, a "defensive" move by one side may look "provocative" to the other, evoking from the latter a further "defensive" reaction which serves only to confirm the suspicions of the former.

With the perception of the enemy, suspicions, and mirror images, North and South Korea have been engrossing in accelerating the military tension and arms race with the object of shielding their own nations. More powerful and offensive armaments have been deployed forward near the Demilitarized Zone (DMZ) on the Korean peninsula. The borderline between what is allowed and what is forbidden is thus unclear: many combat campsites, concrete barriers and the like have been established (Jonsson 2009, 41). But neither ROK nor DPRK has confidence to overwhelm each other in military capability.

Seoul has maintained reliable relations with the United States, whereas Pyongyang has maintained its relations with China. As South Korean national power in security and economic capabilities strengthens, South Koreans want to change the U.S.-ROK relationship from patron-client to partners. On the other side, Beijing's Korea policy has traveled the route from being a Pyongyang-only "one-Korea policy," to a de facto "two-Koreas policy," and then to a Seoul-centered "one-and-a-half-Koreas policy" (Yi 2002, 351). The "one-and-a-half-Koreas policy" would contribute to establish a strategic and economic partnership between PRC and ROK.

To North Korea, China has maintained a 61 year tradition of relationship; it could be called blood pledge relations sealed in blood during the Korean War. Recently, the DPRK-China relationship has grown to the comprehensive partnership including economy, energy, science, and technology from the existing military and security cooperation emphasizing the countries' alliance (Cho 2009, 87), in spite of China's burden on North Korea and North Korea's nuclear proliferation. Although the two countries' relations sometimes appears to be estranged, China has provided massive military and economic aid to North Korea, which has an important effect on North Korean politics and economic stability (Xu 2003, 64). Benefiting from the division between North and South, China could maintain such close Sino-North Korean relations (Qiangguo bbs 2009). Under this situation, Beijing's positive mediation in North and South reconciliation and solving North Korean nuclear affairs is possible.

Second, from the ideological perspective, communist North Korea is obviously favorable toward China. Ideological consideration is one of the most important reasons for Chinese government dispatching troops to Korea. Mao Zedong once said (Yin 2009) to Zhou Enlai: "Korea and us are socialist countries led by the communist party, we cannot took our hands off and witness the enemy perishing Korea."

After the collapse of Eastern European and Soviet Union, the socialist camp declined enormously, and the Western countries cheered on "the End of History" that Francis Fukuyama (2006) named. In recent years, the survival of the North Korean regime and reform of North Korea - what is often dubbed "Status Quo Plus" are China's greatest challenge and prime objective respectively (Kim 2004, 162). Some existing socialist countries started to carry out some reforms, and they are not legitimate socialist countries anymore according to the view of western people. Although we can not define what is a true socialist country today, China, North Korea, Cuba, Vietnam, and Laos are still generally believed to be socialist countries.

According to the western international relations theory of "the democracy and the commentary," the socialist countries do support each other because of the ideological similarities. For instance, Pyongyang clearly supports 
Beijing's position with respect to the Tibet independence issue. And Cuba and Venezuela have a similar standpoint.

In addition, since there are several socialist countries now, everyone has great symbolic significance. The collapse of North Korea might have a negative influence on China, which publicizes the socialist system's superiority and the historical inevitability domestically. China would prefer to see North Korea survive as an independent entity for the foreseeable future, slowly modernizing its economy and strengthening its governing capabilities to enhance stability and economic opportunity (Perry and Schoff 2010,11). But no matter how much North Korea develops at present, the current Chinese government may not want North Korea to vanish easily and may offer emergency procedures, such as supporting China-friendly groups, providing the urgent economy and military assistance, and so on to "rescue the market," but China may not support North Korea by military occupation.

Third, the existence of the Korean peninsula issue can be attributed to Sino-U.S. cooperation. The Chinese people generally believe that as long as North Korea exists, its nuclear issue, weapons of mass destruction (WMD) proliferation and the missile issue, and the conventional weapons disarmament can hardly be solved. These would be the main subjects for Washington. In fact, even though the North Korean nuclear problem is solved, Pyongyang will be continually faced with the problem of power succession, terrible economic conditions, unification, and so forth. So long as these problems exist, Washington has to exert itself, because Pyongyang is challenging U.S. authority unceasingly.

In process of solving the Korean issues, Washington has to seek Chinese assistance since it is not willing to discuss with Pyongyang alone and equally. What is more, Washington lacks enough influence on Pyongyang. For one thing, because China and North Korea have close personnel and trade intercourse, it is difficult for the United States to effectively implement sanctions against North Korea as long as China does not participate. Therefore, Washington would rather Beijing play a more important role in the North Korean issue and hesitates to provoke China. If the United States does not have enough energy for the Taiwan issue, Taiwan may maintain restraint. This was shown clearly during the time when Chen Shui-Bian was the leader of Taiwan.

Furthermore, because the Korean peninsula is divided, North Korea has a vigilant psychology towards South Korea. China may develop North Korean resources by utilizing the friendship of the two countries, developing North Korea's market, and providing good conditions for domestic development. It is helpful for North Korean survival, preventing the regime collapse.

\section{Chinese people's condition to support Korean unification}

On general principle, China supports Korean unification based on national morality, China's diplomatic policy, and real interest. Because China has been suffering from a painful country division, it supports Korean unification. China has no reason to oppose Korean unification. The Chinese populace always believes that an artificially divided nation, no matter how long the period of time and how deep their accumulated grievances are, they will implement unification in the end. It is believed to be the irresistible historical diagnostic method and the inevitable historical development trend. So, Korean unification has the historical complex and will be the nice goal.

From the China's viewpoint on Korean unification, there are several negative and affirmative expectations.

The negative expectations are as follows (Kim 2002, 130): (1) a unified Korea would remove the DPRK as China's critical buffer zone; (2) Korean unification would diminish Beijing's leverage in Korean and world affairs, including its relations with the United States on these issues; (3) Korean reunification could spew more refugees from the North into China's northeastern provinces (in the case of a sudden collapse of the North Korean regime); and (4) a unified Korea could bring about possible territorial conflicts on China's border.

On the other hand, such likely affirmative expectations are as follows (Yi 2002, 338): (1) the emergence of a unified Korean peninsula will change the power structure in East Asia permanently; (2) a unified Korea will become vital for Chin's strategy to contain America in East Asia; (3) a unified Korea will play a key role and become one of the most important partners in China's economic development; and (4) Korean unification will facilitate the eventual reunification between mainland China and Taiwan.

Considering the advantages and disadvantages of the political division on the Korean peninsula, from the Chinese perspective based on the negative and affirmative views on Korean unification above mentioned, it is thinkable that the division has more disadvantages for Chinese long-term development, while a unified, peaceful, and stable Korean peninsula would be more fruitful for Chinese interests. In addition, China has painfully 
experienced the division as well and no doubt prefers a unified Korea as soon as possible. These factors are explained in detail from the Chinese people's view.

First, the Chinese people would like to see a unified Korea. Many Chinese netizens believes (Sohu Forum 2008) that China is a country that benefits from Korean peaceful unification. They also believe that a unified Korea may permanently eliminate the huge unstable hidden trouble of the Chinese periphery (Xu 2003, 60), so China's peripheral environment will be more stable. Then, China may have more vigor to do other work and devote itself wholeheartedly to domestic development and to solve the Taiwan issue.

Second, a unified Korea will be a giant market of 70 million people, thriving commercial relationship. It is noted that Beijing has been gently pursuing its long-term interests and influence on the peninsula while maintaining and expanding room for future policy choices, all with an almost unique patience and stamina (Shi 2009, 44). Considering that China is the largest trading partner of South Korea, and the latter is the third largest trading partner of the former, a prosperous Korea will contribute to the long-time prosperity and stability in the Far East and Northeast Asia. It also will be helpful for a Chinese strategy to develop for the Northeast region. The unified Korea will be the new destination of Chinese investment as well, and China obviously may obtain the economic benefit from a unified Korea. Each country will be a market for the other's goods as well as a source of interdependence for advanced technologies and various investments, with others lack (Son 2003, 85). In addition, the unified Korea will automatically eliminate the burden of Chinese massive economic aid to North Korea every year (Chen 2001, 9).

Third, as for the evolution of Chinese unification policy towards the Korean peninsula, based on various considerations made in this paper, Chinese policies on Korean unification have been changing. Some are determined by the adjustment of Chinese foreign policy, and others by the international environment change. Being affected by world politics and the Korean peninsula situation, Chinese policies on supporting Korean unification experienced a winding development process. Under the cold war system, China for quite a long time unconditionally supported all suggestions and measures proposed by North Korea. As early as the Geneva Conference, which was held sooner after the Korean ceasefire, China firmly supported the standpoint of unification and that foreign countries' army should withdraw from Korea and hold free election. After that, whenever North Korea offers a unification proposition, Chinese leaders always expresses firm support (Liu 2007, 78).

China always supports North Korea's standpoint, which has lead some people to have suspicions about Chinese diplomacy. It can be said that China has some insufficient or not objective part of its Korean peninsula policy and unification issue. It is more or less affected by the Pyongyang's standpoint and policy. So it has not truly implemented an independent diplomacy according to the Chinese national interest and the fact of affairs to carry out its policy.

In the 1980s, along with foreign policy's adjustment, Chinese policy on Korean peninsula countries also changed. After China and South Korea established diplomatic relations, China performed more initiatives on the Korean peninsula issue and initially got rid of some kind of passive aspects. Beijing explicitly announced that it would support all the suggestions and effective action on both sides to promote and realize Korean unification. China changed views and attitudes about North Korea always being right and beneficial for unification, while the South always being wrong and anti-unification (Liu 2007, 79). In November 2005, Chinese President Hu Jintao (2005) visited South Korea and announced seriously: "China welcomes the positive progress between the North Korean and South Korea reconciliation cooperation, reiterated that China would continue supporting North and South to improve the relations steadfastly till realizing the peaceful unification finally."

As concerns the unification condition, although the Chinese government consistently supports unification, this standpoint also has some prerequisites.

First, unification should be independently done without interference from the outside. China, which is also part of the unification issue, insists on the Five Principles of Peaceful Co-existence Diplomacy (2004) that includes mutual respect for sovereignty and territorial integrity, mutual nonaggression, mutual noninterference in internal affairs, equality and mutual benefit, and peaceful coexistence; it is especially opposed to external interference in internal affairs. Although the North and the South are the two countries on Korean peninsula, they are one ethnic identity; the spilt is a short phase of unification in the peninsula's history. Since it is an internal affair, China would neither interfere in the unification issue nor agree to other country's involvement in the Korean peninsula. Because only the independent unification will not create an exclusive mood, China will not care who takes the leading part. At the same time, China will not care whether North and South Korea merge as one unified country or one country with two system models. 
Supporting peaceful and voluntary process of Korean unification, the Chinese does not want German-style unification that means unification by absorption of one part by the other because of worry of bringing chaos to the Korean peninsula and threaten China's security (Park 2010, 125). It is because any dramatic change or tumultuous event on the peninsula is not conducive to China's national interest in the peace and stability of the region (Zhang 2001, 140). Likewise, it is wished to avoid provoking war, riot, or creating the confusion in China or the periphery.

Unification by force does not correspond with China's national interest. The unification by force not only opposed the basic maxim of international relations, but also brings great pressure on China regarding border management. It may also threat Chinese security, because a war would possibly result in the involvement of surrounding countries (Jun 2006). From the broad perspective, it mismatches the Chinese creating peace peripheral environment foreign policy, and it will bring enormous negative influence on Chinese economic development.

A unified Korean military would also be trouble for China. China and North Korea have signed the Friendly Co-operation and Mutual Assistance Treaty between the People's Republic of China and Democratic People's Republic of Korea. The second article reads (Sino-North Korea's Friendship, Cooperation and Mutual Assistance Treaty 2011): "In the event of one of the Contracting Parties being subjected to the armed attack by any state or several states jointly and thus being involved in a state of war, the other Contracting Party shall immediately render military and other assistance by all means at its disposal." If China dispatches troops, China, South Korea, and the United States may possibly resort to arms in the peninsula once more. In the end, China may be facing serious losses. If China does not dispatch troops, it will disobey the good faith of North Korea; therefore, China opposes military unification firmly.

Moreover, it is wished that the unified Korea should be denuclearized. China firmly believes that the both sides of the Korean peninsula should be denuclearized because a unified Korea with nuclear weapons would have a strong impact in the region. In fact, the U.S. Congress' recent research (Chanlett-Avery and Nikitin 2009, 12) also demonstrated that the unification of Korea will lead to Korea possessing nuclear weapon, and Japan may also build nuclear weapons.

Finally, the Chinese people want the unified Korea to be neutral or friendly towards China, which reflects the historical logic. It will contribute to the Chinese peripheral diplomacy and peacefulness of Northeast Asia. In addition, the Chinese think that it will contribute to establishing a Northeast Asia community in the future. After the Cold War, the U.S. hegemony might be the biggest threat for China. This threat is omni-directional and strategic, and the Korean peninsula is one of the fronts for the U.S. Asian and Pacific strategy to contain China. Especially in conditions where no multilateral security mechanisms exist in Northeast Asia, it generally has "the security dilemma" among big states (Liu 2007, 54). Further, China does not want the unified Korea to become a pro-American state or a non-friendly one; it prefers the withdrawal of the U.S. armed forces from South Korea as soon as possible (Kang 2009, 69).

These views are shown in a public survey (Moon et al 1998, 98): 61.9\% of Chinese scholars who are experts on the Korean issues support Korea neutralized unification and the withdrawal of the U.S. armed forces from South Korea. The view on Korean neutralization is well supported by Richard Chadwick (2007, 53-54): A unified Korea or demilitarized Korea, perhaps along Swiss lines, could act as a bridge for its neighbors to help them continue to change their foreign policies both materially and ideologically into a framework of cooperative rather than conflictual economic and ideological competition. It can be supported by the expectation of resolving the conflicts between South and North Korea, of war prevention on the Korean peninsula, of avoiding foreign aggression and intervention after Korean unification, and of building peace and stability in the form of the multilateral security system in Northeast Asia (Kang 2009, 67). A larger, united Korea, freed of a permanent military threat, would logically pursue a more self-confident foreign policy, reducing the role of the United States on the peninsula (Lukin 2009, 57). These views coincide with that the unified Korea is groped for neutralization or buffer zone without station of U.S. troops on the Korean peninsula. In spite of that, they will not likely get support from the Koreans.

Moreover, China does not want to see an alliance with the United States in Korean peninsula, or developed towards the U.S., Japan and South Korea triangle alliance. Because after solving the Korean issue, if U.S. forces in Korea continue to be stationed there, the direction of the alliance is mute. It will either suspect Chinese intention, contain China's development, or prepare for interference on the Taiwan issue. China is not willing to see U.S. troops appears on the Yalu River bank, not only because this will remind them of the painful memory of the Chinese populace a half century ago, but also because it will pose a serious threat to China's national security. 
Because of this, China would mention many times that China does not favor a country garrison in a foreign country. The U.S. forces garrison in Korea is a historical problem left after WWII. It should be solved properly by the concerned parties through consultation (Xu 2003, 60).

\section{Conclusion}

"The Romance of the Three Kingdoms," which is acclaimed as one of the Four Great Classical Novels of Chinese literature, wrote at the preface: "Here begins our tale. The empire, long divided, must unite; long united, must divide." Similarly the Chinese people who have suffered bitter division believe that the Korean peninsula, which was divided because of the Cold War, will be reunified in the end. And China appears not to have the so-called territorial ambition as well as any intention to dispatch troops to North Korea by creating a confusing situation and make it into an established fact. It also presents its will to continue propelling the construction of a "harmonious society" domestically, and exposing that the "Chinese threats theory" is fictionalized.

Ensuring peace, harmony and prosperity for China's neighbors in terms of "peaceful rise" or "harmonious world" diplomacy, China constantly supports peaceful and voluntary process for Korean unification. To Chinese, it is believed that this way is ideal and can assure the lasting stability of the Korean peninsula. Korean unification will be sure to contribute to improve Northeast Asian security environment. In the longer term, de-nuclearized and rich in resources and high levels of education, at the center of the world's most dynamic economic region, could be expected to play an ever more prominent role, perhaps the core role in the construction of the Northeast Asian Community (McCormack 2007). If a unified Korea adopts the neutrality, withdrawal of U.S. armed forces on the Korean peninsula may be possible. Thereby, China may largely reduce or even withdraw the frontier troops from the border, then develop the Yalu River and the Tumen River basin areas together, and make a prosperous auspicious border.

From national interest's perspective, China hopes to see Korean unification that would be in favor of China, at least it will not bring negative influence. It also desires for the unified Korea that is neutral or friendly towards China, and for the withdrawal of the U.S. armed forces from the Korean peninsula. Otherwise China wants to maintain the status quo and the present situation. Although this is not supported by the Koreans, China will fully support reconciliation and cooperation, political dialogue, economic and cultural exchanges between North and South Korea. It is believed to contribute to keep good relations between them, leading to a peaceful process unification in the end.

Obviously, the direction of the Korean peninsula's move toward unification will be decided to a great extent by the efforts of South Korea in the unification process. South Korea needs to eliminate the anxiety of the Chinese population, and guarantee that a unified Korea may be able to contribute to China's benefit, or will not harm Chinese interests at least. Then, it will possibly receive in exchange the Chinese people's overwhelming support and the positive impetus towards Korean unification.

\section{Acknowledgement}

This study was supported by Dong-A University research fund. We thank the university.

\section{References}

Bennett, Bruce W. (2009). North Korea's WMD Capability and The Regional Military Balance: A U.S. Perspective. The Korean Journal of Security Affairs, December, 14(2), 7-35.

Brzeginsky, Zbigniew. (1998). The Grand Chessboard: American Primacy and Its Geostrategic Imperatives. Shanghai: Shanghai People's Press.

Cai, Jian. (2007). Six-party Talks and the Establishment of a Northeast Asian Regional Security Mechanism. The Journal of Peace Studies, 8(2), 97-130.

Chadwick, Richard. (2007). Korean Foreign Policy Challenges in the $21^{\text {st }}$ Century: Threats and Opportunities for Security, Peace and Prosperity in East Asia. The Journal of Peace Studies, 8(2), 35-57.

Chanlett-Avery, Emma and Mary Beth Nikitin. (2009). Japan's Nuclear Future: Policy Debate, Prospects, and US Interests. CRS Report for Congress, February 19, 1-13.

Chen, Fengjun. (2001). The Korean Peninsula's Strategic Meaning towards China in $21^{\text {st }}$ Century. International Politics Research, 4.

Chen, Fengjun. (2002). Asian-Pacific Major Powers and Korean Peninsula. Peking: Peking University Press.

Cheon, Seongwhun. (2011). Changing Dynamics of US Extended Nuclear Deterrence on the Korean Peninsula.

Pacific Focus, April, 26(1), 37-64. http://dx.doi.org/10.1111/j.1976-5118.2011.01055.x 
Cho, Seong-Ryoul. (2009). North Korea's Security Dilemma and Strategic Options. The Journal of East Asian Affairs, Fall/Winter, 23(2), 69-102.

Cho, Young Chul. (2008). South Korea's Security Practice from 1945 to 1998: A Critical Review. The Journal of Peace Studies, 9(4), 143-176.

Cumings, Bruce. (1997). Korea's Place in the Sun: A Modern History. New York: W. W. Norton \& Company, Inc.

Fukuyama, Francis. (2006). End of History and the Last Man. New York: Free Press.

Gladstone, Arthur. (1959). The Conception of the Enemy. Journal of Conflict Resolution, June, (2), 132-137.

He, Fangchuan. (1998). On Chinese Suzerainty System. Peking University Journal (Philosophy and Social Science), 6.

Hong, Ki-Joon. (2009). Path Dependence in the Six-Party Talks. The Korean Journal of Security Affairs, December, 14(2), 69-89.

Hu Jintao's Address in the South Korean Congress. (2005). Strengthens Friendship and Cooperation, Creates the Glorious Future. [Online] Available: http://www.fmprc.gov.cn/chn/zxxx/t221997.htm (November 17, 2005)

Hwang, Doo-hyong. (2009). U.S. Welcomes S. Korea's Move to Fully Join PSI: State Dept. Yonhap News Agency, April 9.

International Crisis Group. (2006). China and North Korea: Comrades Forever? Asia Report, February, (112), $1-37$.

Jonsson, Gabriel. (2009). Peace-keeping in the Korean Peninsula: The Role of Commissions. KINU Research Monograph 09-15. Seoul: Korea Institute for National Unification.

Jun, Yang. (2006). On Chinese and Korean Peninsula Relations History. Social Science Literature Press.

Kang, Jong-il. (1997). A Power Politics Analysis of Korea's Loss of Autonomy: Korean Internal and External Relation with the United States: 1871-1903. Ph.D. diss., University of Hawaii.

Kang, Jong-il. (2009). A Study on Permanent Neutrality Unification of Korea. The Journal of Peace Studies, 10(2), 51-71.

Kim, Heungkyu. (2010). From A Buffer Zone to A Strategic Burden: Evolving Sino-North Korea Relations During the $\mathrm{Hu}$ Jintao Era. The Korean Journal of Defense Analysis, March, 22(1), 55-74. http://dx.doi.org/10.1080/10163270903526359

Kim, Samuel S. (2002). China, Japan, and Russia in Inter-Korean Relations. In Kongdan Oh and Rapph C. Hassig (Eds.). Korea Briefing 2000-2001: First Steps Toward Reconciliation and Reunification. New York: M.E. Sharpe, Inc.

Kim, Samuel S. (2004). China's New Role in the Nuclear Confrontation. Asian Perspective, 28(4), 147-184.

Lee, Dong Ryul. (2010). China's Policy and Influence on the North Korea Nuclear Issue: Denuclearization and/or Stabilization of the Korean Peninsula? The Korean Journal of Defense Analysis, June, 22(2), 163-181. http://dx.doi.org/10.1080/10163271003744421

Lee, Keum-Soon et al. (2009). White Paper on Human Rights in North Korea. Seoul: Korea Institute for National Unification.

Liu, Jinzhi. (2007). Chinese Foreign Policy towards the Korean Peninsula Country. World Economics \& Politics, 5.

Liu, Xuelian. (2007). Analysis on Chinese Geography Security Strategy in Korean Peninsula. Northeast Asia Forum, September, 116(15).

Lukin, Alexander. (2009). Russia's Korea Policy in the $21^{\text {st }}$ Century. International Journal of Korean Unification Studies, 18(2), 30-63.

Maass, Matthias. (2010). The North Korean Nuclear Program: From a Conditional Bargaining Chip to the Ultima Ratio in Deterrence. The Korean Journal of Security Affairs, June, 15(1), 31-54.

McCormack, Gavan. (2007). A Denuclearization Deal in Beijing. Z Net, February 14.

Moon, Soo-eon et al. (1998). International Polities of Korean Unification and Multilateral Security Cooperation in Northeast Asia. The Korean Journal of International Relations, 37(3), 77-115. 
Park, Changhee. (2008). Why China Attack: China's Geostrategic Vulnerability and Its Military Intervention. The Korean Journal of Defense Analysis, September, 20(3), 263-282. http://dx.doi.org/10.1080/10163270802309204

Park, Hun-Bong. (2010). China's Position on Korea's Unification and US Forces Korea. The Journal of East Asian Affairs, Spring/Summer, 24(1), 117-154.

Perry, Charles M. and James L. Schoff. (2010). Consensus Building and Peace Regime Building on the Korean Peninsula. International Journal of Korean Unification Studies, 19(1), 1-28.

Pollack, Jonathan D. (2009). The Major Powers and the Two Koreas: An Uneasy Transition. The Korean Journal of Defense Analysis, March, 21(1), 1-9. http://dx.doi.org/10.1080/10163270902745588

Qiangguo bbs. (2009). If Unify Taiwan, We Must Maintain the North Korean's Security. [Online] Available: http://bbs.chnqiang.com/viewthread.php?tid=61728 (June 12, 2009)

Rozman, Gilbert. (2004). Northeast Asia's Stunted Regionalism - Bilateral Distrust in the Shadow of Globalization. Cambridge: Cambridge University Press. http://dx.doi.org/10.1017/CBO9780511617126

Shi, Yinhong. (2009). China and the North Korean Nuclear Issue: Competing Interests and Persistent Policy Dilemmas. The Korean Journal of Defense Analysis, March, 21(1), 33-47. http://dx.doi.org/10.1080/10163270902745620

Sina Military Forum. (2007). China Would Neither Abandon or Get Rid the North Korea, What the Result? [Online]

Available: http://bbs.news.sina.com.cn/tableforum/App/view.php?bbsid=4\&subid=0\&fid=142461\&tbid=7616 (October 2 , 2007)

Sino-North Korea's Friendship, Cooperation and Mutual Assistance Treaty. (2011). [Online] Available: http://baike.baidu.com/view/485899.htm (May 25, 2011)

Sohu Forum. (2008). [Online] Available: http://club.news.sohu.com/r-zz0382-126188-0-0-0.html (August 8, 2008)

Son, Dae Yeol. (2003). The Role of China in Korean Unification. Master's thesis, Naval Postgraduate School.

Stagner, Ross. (1965). The Psychology of Human Conflict. In Elton B. McNeil (Ed.). The Nature of Human Conflict. Englewood Cliffs, N.J.: Prentice-Hall.

Tianya Forum Netizen's Article. (2006). What the Sino-North Korea's Friendship, Cooperation and Mutual Assistance Treaty Brought to China [Online] Available: http://sxsd.groups.tianya.cn/bulo/ShowArticle.asp?ArticleID=530756\&buloID=14260\&idWriter=0\&Key=0 (July 7, 2006)

Wang, Xiaofu. (2006). China and Foreign Countries' Cultural Exchange History in Ancient Days. Higher Education Press.

$\mathrm{Xu}$, Weidi. (2003). Solving Korean Peninsula Nuclear Crisis and Stepping out of the Cold War. World Economics \& Politics, 9 .

Yi, Xiaoxiong. (2002). Ten Years of China-South Korea Relations and Beijing's view on Korean Reunification. The Journal of East Asian Affairs, Fall/Winter, 16(2), 315-351.

Yin, Jiamin. (2009). Backstage Documentary of Mao Zedong's Decision-making on Dispatching and Withdrawal Army to Resist US's Aggression and Aid Korea. Severn Days of Chinese Communist Party's History, March, 48.

Zhan, Debin. (2008). Beyond the Hostility: An Analysis on the U.S.-North Korean Relations by Game Theory. The Journal of Peace Studies, 9(4), 29-61.

Zhang, Xiaoming. (2002). China and Inter-Korean Relations. Asian Perspective, 26(3), 131-144.

(2000). China Hoped that the Summit Makes the Positive Progress. Lianhe Zaobao, June 14.

(2009). S. Korean People Ignore the Terrible North Korean Human Rights. The Independent, April 24. 